Atıf/Citation: Göl, H. \& Sakız, H. (2020). Okul öncesi eğitimde rehberlik programının kapsayıcı eğitim ilkeleri doğrultusunda tasarlanması. Nitel Sosyal Bilimler, 2(2), 90-115.

\title{
Okul Öncesi Eğitimde Rehberlik Programının Kapsayıcı Eğitim İlkeleri Doğrultusunda Tasarlanması
}

\author{
${ }^{\mathrm{a}}$ Hakan Göl ${ }^{1}$, bHalis Sakız \\ a Yüksek Lisans Öğrencisi, Mardin Artuklu Üniversitesi, Türkiye \\ ${ }^{b}$ Doç. Dr., Mardin Artuklu Üniversitesi, Türkiye
}

Öz

Kapsayıcı eğitim; hiçbir öğrencinin diline, kültürel yapısına, milletine, cinsiyetine, gelir düzeyine, sosyal sınıfına göre ayrımcılığa uğramaksızın tüm öğrencilerin eğitim olanaklarından adil ve eşit şartlarda ihtiyaçları ve ilgileri doğrultusunda faydalanmasını sağlayan bir süreci ifade etmektedir. Kapsayıcı eğitim sayesinde sınıf ortamında geç öğrenen veya herhangi bir engeli olan bireyler, göçmenler, farklı dini veya farklı etnik kimliğe sahip olan bireyler de her öğrenci gibi eğitim olanaklarından faydalanmakta ve bu bireylerin eğitim ortamından maksimum seviyede verim alması sağlanmaktadır. Bu çalışmanın amacı okul öncesi eğitim rehberlik programının kapsayıcı eğitim ilkeleri doğrultusunda yeniden düzenlenmesi ve Milli Eğitim Bakanlığının yayınlamış olduğu okul öncesi rehberlik programının kapsayıcı bağlamda yeniden tasarlanması adına bir öneri sunmasıdır. Bu çalışmada Milli Eğitim Bakanlığının yayınlamış olduğu okul öncesi rehberlik programında geçen yeterlik alanları, kazanımlar ve etkinlikler detaylı bir şekilde incelenmiş, kapsayıcı eğitim programının ilkeleri, değerleri ve felsefesi doğrultusunda yeniden tasarlanmıştır.

Anahtar Kelimeler: kapsayıcı eğitim, okul öncesi eğitim, rehberlik programı, kapsayıcı rehberlik

\footnotetext{
'Sorumlu Yazar/Corresponding Author: (DD) Hakan Göl, Mardin Artuklu Üniversitesi, hakangol21@ hotmail.com, Türkiye 


\title{
Designing an Inclusive Guidance Program in Preschool Education
}

\author{
Extended Summary
}

Inclusive education defends that all educational institutions should be open to all students and all students should be given equal opportunities by this institution to take advantage fairly. In fact, equality in opportunity in education is involved among the principles of the Ministry of National Education. Yet, by using the principles of equality in opportunity, the focus is mostly on gender and socioeconomic circumstances. This situation causes the negligence of immigrants, different ethnic and religious identities and disabled individuals. This situation which is neglected is tried to be solved under the lights of inclusive education not only for disabled people and immigrants but also for all students to get equal education. In recent years, schools are reorganized in terms of these conditions. Instructional programs are important tools to provide inclusive education for all people (Sak1z, 2016).

They should be designed in an inclusive way to be accessible to all individuals by responding to the needs of all students, to achieve their goals and to ensure that all students receive the necessary efficiency from their instructional programs. Thanks to an inclusive curriculum, students adapt to the educational environment more easily and reduce the risk in education (Stark \& Bloom, 1985). While creating a preschool educational counseling program, the program should be inclusive to cover all segments of the society without discriminating, between any gender, race, religion or social class.

Preschool education covers 36-66 months in Turkey. This is the period when children's brain development is the fastest (MEB, 2013). In addition, the personality structures and value judgments of children are shaped depending on behaviors in this period. What the child will learn, how much to learn, what to discover and how fast she can learn in this period is directly proportional to the support which is given to the child by her environment. In this context, it can be said that the education which is given to children in preschool education affects the whole life of children.

In order to appeal to all students in the education program, it was prepared by considering the principles of inclusive education such as education, equality and suitability for everyone. This program is a guidance program prepared for one semester inclusive education for preschool education. In this preschool education guidance program, there are a total of 83 learning outcomes and 10 activities related to seven competence areas. Also, this program includes six selected learning outcomes and two activities as samples. Explanations are given to explain the activities and outcomes which are stated in the content of the program to student more effectively and to make the process more inclusive.

By providing programmed teaching and guidance services to children, children can overcome this period without any obsession and adapt to the school and society. The counseling program in preschool education aims at adapting children to school and the environment, developing a positive attitude towards learning, selfknowledge, developing sensitivity towards family, friends and other members of the society and raising awareness of the importance of professions in human life (MEB, 2012). The counseling program which is 
created to bring these goals to the students should be flexible enough to meet different needs of the students and school staff, while parents should be in cooperation.

There are seven competence areas in this program. These are adaptation to school and environment, educational development, self-acceptance, interpersonal relationships, family and society, safe and healthy life and professional development. Learning outcome is to express the knowledge, skills and attitudes that students are expected to learn in the process. Explanations include statements that will help teachers in application of the activities of learning outcomes. Inclusive education programs envisage designing alternative skills and acquisition areas in relation to students' preferences and needs (Booth \& Ainscow, 2002). The variety of program elements has been increased and rich program content has been produced according to different student characteristics in terms of number of choices.

As known, most of the outcomes related to counseling are not achievable in 40 minutes. Some outcomes require a maturation process. Thus, it should be known that the process of evaluating students is a process. While evaluating students in this process, attention should be paid to the characteristics if inclusive education such as equality (assessment of all students under fair conditions), sensitivity to cultures (using contents which is related to cultures of different groups in assessment tools, showing cultural sensitivity, avoiding racism), complementarily (no scoring, process-oriented and formative), differentiation (according to students' needs making parallel translation, automatic marking, exams with large fonts and headphone), authenticity (being connected with real life), democratization (students take responsibility by evaluating themselves and their peers) (Taneri, 2019).

When the preschool education counseling programs published by the Ministry of National Education are examined, it has been understood that the activities and learning outcomes do not pay attention to the students' individual differences sufficiently. Therefore, in this study, the aim is to make the preschool education guidance program published by the Ministry of National Education suitable for inclusive education. For this purpose; competence areas, learning outcomes and activities which is stated in this program are examined one by one. As an example, six outcomes and two activities are included in the study and notes are written under each of them to make them suitable for inclusive education. In this way, it is aimed that individuals who are visually, mentally disabled and hearing impaired, who are backward, whose parents are illiterate and who has different languages from official language of the country to participate in the activities and get the highest level of efficiency from these activities.

Every student cannot have the cognitive, emotional and psychomotor competence level that can achieve the specified standard outcomes. For this purpose, counselors and teachers should consider the level of students' readiness before the process when applying the outcomes. After the preliminary measurement and preliminary evaluations, which are among the inclusive education principles, the necessary infrastructure should be determined appropriate outcomes should be determined for each student and these objectives should be targeted. Keywords: inclusive education, education of preschool, program of guidance, inclusive guidance 


\section{Giriş}

Okul öncesi eğitim, çocukların duygusal, sosyal ve kişisel alanlarda gelişimi için temel beceri ve davranışların kazandırıldığı önemli bir eğitim aşamasıdır (Melhuish, 2011). Söz konusu alanlardaki gelişim evde başlarken, okul öncesi eğitim kurumlarında aynı yaş grubundan çocuklar ve öğretmenler ile kurulan iletişim, çocukların becerilerinin gelişmesine yol açmaktadır. Okul öncesi kurumlarda gelişim ve öğrenme düzeyinin azami düzeyde gerçekleşmesinde uygun bir program dâhilinde tasarlanan ve uygulanan rehberlik hizmetlerinin önemli bir rol oynadığı bilinmektedir. Ancak rehberlik programlarının çocukların gelişim ve öğrenme düzeylerini artırabilmesi, programın tüm bireylerin eğitsel ihtiyaçlarının karşılandığı ve eğitim olanaklarından faydalandığı kapsayıcı bir eğitim modeli etrafında tasarlanmasına bağlıdır. Bu çalışma, Türkiye'de mevcut okul öncesi rehberlik programının kapsayıcı eğitim ilke ve uygulamalarına göre yeniden düzenlendiği bir içerik sunmaktadır.

\section{Okul Öncesi Eğitim ve Türkiye’de Okul Öncesi Eğitimde Rehberlik Programı}

Türkiye'de okul öncesi eğitim 36 - 66 aylık dönemleri kapsamaktadır. Bu dönem çocukların beyin gelişiminin en hızlı olduğu dönemdir (Milli Eğitim Bakanlığı [MEB], 2013). Ayrıca bu dönem çocuklarının kişilik yapıları ve değer yargıları, eğitim ve öğretim sürecinde kazanılan davranışlara bağlı olarak şekillenebilmektedir (Başal \& Kahraman, 2018). Bu dönemde çocuğun ne öğreneceği, ne kadar öğreneceği, neler keşfedebileceği ve hangi hızla öğrenebileceği çocuğa çevresi tarafından verilen destek ile doğru orantılıdır (MEB, 2013). Bu bağlamda okul öncesi dönemde verilen eğitimin çocukların tüm yaşamını etkilediği söylenebilir. Çocuklara nitelikli bir öğretim programı kapsamında verilecek rehberlik ve danışmanlık hizmetleri, çocukların bu dönemi gelişim düzeyine uygun geçirmesini, eğitim aldığı okula ve yaşadığı topluma uyum sağlamasını kolaylaştırabilmektedir.

Türkiye'de okul öncesi eğitimde rehberlik programı yoluyla çocukların okula ve çevreye uyum sağlaması, öğrenmeye karşı olumlu tutum geliştirmesi, kendini tanıması, aile, arkadaş ve toplumun diğer üyelerine karşı hassasiyet geliştirmesi ve mesleklerin insan hayatındaki önemine ilişkin farkındalık geliştirmesi amaçlanmaktadır (MEB, 2012). Bu amaçların öğrencilere kazandırılması için rehberlik programının öğrencilerin farklı ihtiyaçlarına cevap verebilecek düzeyde esnek olması, okul çalışanlarının ve velilerin işbirliği içerisinde çalışabilmesini sağlaması gerekmektedir.

Okul öncesi eğitimde öğretmen, eğitimin niteliğini ve çocuğun gelişimini etkileyen en temel faktörlerden biridir (MEB, 2013). Öğretmenlerin sınıf içerisinde eğitimin gelişime uygunluk ilkesini göz önünde bulundurup tüm öğrencilerin gelişim seviyelerinin ve kişisel özelliklerinin farkında olması gerekmektedir. Öğretmenler öğrencilerin farklılıklarını göz önüne alarak kendileri ile tutarlı ve öğrenci merkezli bir ilişki geliştirdiğinde, öğretmenlerin eğitim niteliğinin artırılmasına ve bu nitelikten öğrencilerin azami düzeyde faydalanmasına katk1 sunacağı bilinmektedir (Düşkün, 2016).

\section{Kapsayıcı Ĕgitim}


Kapsayıcı eğitim, bir ülkede yer alan bütün eğitim kurumlarının (devlet okulu, özel okul, dershane, kreş vs.) bütün öğrencilere açık olmasını ve herkese eşit firsatlar tanınarak bu kurumlardan bütün bireylerin adil bir şekilde faydalanması gerektiğini savunmaktadır. Nitekim eğitimde fırsat eşitliği ilkesi, Milli Eğitim Bakanlığı'nın temel ilkeleri arasında da yer almaktadır. Son yıllarda fırsat eşitliği ilkesi gözetilerek öğrencilerin yeterlilik düzeyleri, sosyoekonomik koşulları ve cinsiyetlerinden kaynaklanan engeller üzerine odaklanılmış; göçmenlerin, farklı kimlik özelliklerine sahip, öğrenme güçlüğü yaşayan veya engeli olan bireylerin eşit şartlarda eğitim süreçlerine katılması ve bölgeler arası gelişmişlik farkının asgari düzeye indirilmesi için çeşitli çalışmalar gerçekleştirilmiştir. Bu durum kapsayıcı eğitim modelinin tüm öğrencilerin azami düzeyde gelişim ve öğrenmesi için okulların yeniden düzenlenmesi gerektiği anlayışı ile uyum içindedir.

Kapsayıcı eğitim, UNESCO bünyesindeki 'Herkes için Eğitim (Education for All) 'inisiyatifi tarafından tüm bireyleri içine alan bir eğitimin anahtar stratejisi olarak görülür (Düşkün, 2016). Kapsayıcı eğitim öğrenme süreçlerinde öğrencilerin kapasitelerinin maksimum seviyede kullanılması gerektiği ve herkesin her şartta öğrenebileceği görüşüne dayanmaktadır (Özdaş, 2019). UNESCO (2015) kapsayıcı eğitimi ‘tüm öğrenenlerin farklı ihtiyaçlarına cevap verecek şekilde ayrımcılığı azaltıp herkesin topluma katılımını sağlayarak toplumun tüm kesimlerinin ihtiyacına cevap verme süreci 'olarak tanımlamıştır. Kapsayıcı eğitim Çelik (2017) tarafından benzer şekilde ‘öğrenme becerileri, bedensel ya da zihinsel engel durumları, cinsiyet, sosyoekonomik ya da kültürel kimlikleri gibi hiçbir ayrım unsuru nedeniyle dışlanmaksızın tüm öğrencilerin hem zorunlu temel eğitim hem de daha ileri eğitim süreçlerinde ihtiyaçları ve hedefleri doğrultusunda kişisel gelişimlerini sağlayabilecekleri eğitim olanaklarından eşit şekilde yararlanabilmeleri gerektiğini temel prensip olarak benimseyen bir eğitim yaklaşım’ şeklinde tanımlanmıştır. Kapsayıcı eğitimin temel amacı kişilerin farklı özelliklerinden dolayı birbirilerine yönelik ön yargıların ve olumsuz tutumların, dışlamanın ve ayrımcılı̆̆ın ortadan kaldırılarak tüm öğrencilerin okul ortamında ihtiyaçları ve ilgileri doğrultusunda nitelikli eğitimden faydalanmasıdır (Oral, 2016). Özetle kapsayıc1 eğitim kimsenin inancına, ait olduğu kültürel yapıya, engel düzeyine, cinsiyetine ve yaşadığ sosyoekonomik koşullara bakılmadan herkesin eşit şartlarda eğitim almasını savunan bir eğitim modelidir (Eğitim Reformu Girişimi, 2016a, 2016b).

Yetersizlik, başarısızlık, farklılık ve engellilik gibi kavramlara yönelik geliştirilen yeni bakış açıları, bu olguların sadece bireysel etmenlerin değil, çevresel unsurların da etkilediği birer sonuç olduğunu, bireyin tümüyle içinde yer aldığı biyoekolojik sistem içinde değerlendirilmesi gerektiğini vurgulamaktadır (Sakız vd., 2015). Bu bakış açısı, kapsayıcı eğitim değer, ilke ve uygulamaları bağlamında yeni danışmanlık ve rehberlik çerçeveleri geliştirilmesine de yardımcı olmaktadır (Kourkoutas \& Xavier, 2010). Bu çerçeveler, bireyin ekosistemi içerisinde değerlendirildiği birey merkezli gelişimsel yaklaşımı içermektedir. Bireyi ve bireyin yaşadığı sistemleri merkeze alan yaklaşımların özellikle çocuklara ve risk altında bulunan bireylere rehberlik ve danışmanlık hizmeti verildiğinde etkili olduğunu gösteren çalışmalar bulunmaktadır 
(Carr, 2009). Bu çalışmanın amacı da, okul öncesi eğitim rehberlik programını kapsayıcı eğitim tanım ve ilkeleri ile uyumlu bir şekilde yeniden tasarlamaktır.

\section{Okul Öncesi Eğitim Rehberlik Programının Yeniden Tasarımı}

Eğitim programları, kapsayıcı eğitimin her bireye nitelikli eğitim sunma hedefinin somut olarak gerçekleştirildiği en önemli araçtır (Sakız, 2016). Eğitim programlarının tüm öğrencilerin ihtiyaçlarına yanıt vererek tüm bireyler tarafından erişilebilir hale gelmesi, genel olarak amacına ulaşması ve tüm öğrencilerin eğitim programlarından gerekli verimi alabilmesi için kapsayıcı bir şekilde oluşturulması gerekmektedir. Kapsayıcı bir program sayesinde öğrenciler eğitim ortamına uyum sağlayabilmekte, eğitim ortamında öğrenmeye karşı olası riskler azaltılabilmektedir (Stark \& Bloom, 1985). Bu amaç ile kapsayıc1 eğitim ilkeleri etrafında tasarlanan okul öncesi eğitim rehberlik programının oluşturulma sürecinde programın cinsiyet, ırk, din, sosyal sınıf ayrımı yapmadan, toplumun tüm kesimlerini içine alan kapsayıcı bir nitelik taşımasına dikkat edilmiştir.

$\mathrm{Bu}$ çalışmadaki rehberlik programının tüm öğrencilere hitap edebilmesi için kapsayıcı eğitimin herkes için eğitim, eşitlik, gelişime uygunluk gibi ilkeleri göz önüne alınmıştır. Bu program okul öncesi eğitimde bir eğitim-öğretim dönemi uygulanabilecek şekilde hazırlanmıştır. MEB'in okul öncesi eğitim rehberlik programında yedi adet yeterlik alanına bağlı toplam 83 tane kazanım ve 10 adet etkinlik bulunmaktadır. $\mathrm{Bu}$ programda ise örneklem olarak seçilmiş altı adet kazanım ve iki adet etkinlik yer almaktadır. Programın içeriğinde yer alan kazanımları ve etkinlikleri öğrencilere daha etkili verebilmek ve süreci daha kapsayıcı hale getirmek için program boyunca detaylı açıklamalara yer verilmiştir.

$\mathrm{Bu}$ programda önerilen kazanımlara ek olarak, bireylerin ihtiyaçları, özellikleri ve tercihleri ile uyumlu olarak, farklı kültürlere karşı farkındalık oluşturulması, kültürel farklılıklara ve çeşitliliğe saygılı ve duyarlı bireyler yetiştirilebilmesi ve dile ilişkin söz varlığının zenginleştirilmesi adına yeni kazanımlar belirlenmiştir. Her ne kadar bu durum, merkezi eğitim ve öğretim programlarının uygulandığı eğitim sistemlerinde zor olsa da, kapsayıcı eğitim programı, içerik açısından esnek bir kazanım listesi belirlenmesini, bu durumun da öğrenci merkezli bir şekilde gerçekleştirilmesini öngörmektedir (Cole, 2008).

Programda yer alan her bir kazanımın edinilmesi için gereken uygulamaların bir ders saati içinde gerçekleştirilmesi öngörülmektedir. Ancak dersin akışına, öğrencilerin özelliklerine ve ihtiyaçlarına göre öğretmen süreyi uzatabilmekte ya da kısaltabilmektedir. Bu unsurlar dikkate alınarak kazanımların gerektirdiği uygulamalar bir ders saatini aşan süreler içinde de gerçekleştirilebilmektedir. Kazanımların edinilmesi adına örnek etkinlikler sunulmuş ve bu etkinlikler hakkında detaylı açıklamalar verilmiştir.

\section{Programın Yeterlik Alanları, Kazanımlar ve Açıklamaları}

$\mathrm{Bu}$ çalışmada tasarlanan kapsayıcı programda yedi yeterlik alanı bulunmaktadır. Bu alanlar (1) okula ve çevreye uyum, (2) eğitsel gelişim, (3) kendini kabul, (4) kişilerarası ilişkiler, (5) aile ve toplum, (6) 
güvenli ve sağlıklı hayat ve (7) mesleki gelişimdir. Her bir alandaki yeterliliklerde gelişim sağlandığının değerlendirilmesi adına çeşitli kazanımlar belirlenmiş̧ir. Kazanım, öğrencilerin süreç içerisinde öğrenmesi beklenen bilgileri, becerileri ve tutumları ifade etmektedir. Kazanımları takip eden açıklamalar ise kazanımların etkinlikler uygulanırken öğretmenlere yardımcı olacak ifadeleri içermektedir.

Kapsayıcı eğitim programları, öğrencilerin tercih ve ihtiyaçlarıyla ilişkili olarak alternatif beceri ve kazanım alanları tasarlanmasını öngördüğünden (Booth \& Ainscow, 2002), program unsurlarının çeşitliliği arttırılmış, farklı öğrenci özelliklerine göre seçim sayısı açısından zengin bir program içeriği üretilmiştir.

Programda yer alan yeterlik alanları ve kazanımlar MEB tarafından oluşturulan okul öncesi eğitim rehberlik programında yer almaktadır. Bu yeterlik alanları ve kazanımlar okul öncesi öğrencilerin (i) yaşamlarını sağlıklı bir şekilde sürdürebilmeleri, başka bir ifade ile onlar için hangi ürünlerin ve hangi davranışların sağlıklı veya zararlı olduğunu bilmeleri, (ii) sınıf ve okul ortamına uyum sağlayabilmeleri, (iii) sahip oldukları güçlü yönlerini tanımaları, (iv) aileleri ve yakın çevreleriyle iyi ilişkiler geliştirebilmeleri ve (v) meslekler hakkında ön yargılardan uzaklaşıp ilerleyen yaşamlarında meslek seçiminde lazım olacak genel bilgileri öğrenebilmeleri açısından önem arz etmektedir. Bu alanlar ve kazanımlar çocuğun okula başlamasından üniversite mezunu oluncaya kadar kendisine her alanda lazım olacak bilgileri içermektedir. Bir sonraki bölümde programda yer alan yedi yeterlik alanı ve bu alanların açıklamalarına yer verilmektedir.

- Okula ve Çevreye Uyum: İlk defa aile ortamından ayrılarak yapılandırılmış bir eğitim programına katılan çocuğun sosyalleşme sürecine katkı sağlaması ve katıldı̆̆ı yeni ortama alışması amacıyla belirlenen bu yeterlik alanında yer alan kazanımlar ile çocuğun, okulun ve sınıfın bir bireyi olarak sosyalleşmesi ve okul içinde olumlu ilişkiler geliştirerek kişiler arası ilişkilerin gelişimine katkı sağlaması amaçlanmaktadır.

- Eğitsel Gelişim: Bu yeterlik alanıyla çocuğun öğrenme hayatına dair olumlu tutumlar geliştirmesi, bağımsız davranabilme adına gerekli becerileri kazanması amaçlanmaktadır.

- Kendini Kabul: Bu yeterlik alanıyla çocuğun kendini kabul etmesi, güçlü ve güçlendirmesi gereken yönlerini ve bireysel farklılıklarını tanıması amaçlanmaktadır.

- Kişilerarası İlişkiler: Bu yeterlik alanındaki kazanımlarla iletişimin önemi, iletişsim kuralları, empati kurabilme, paylaşma, akranlarını tanıma ve birlikte oyun oynama gibi becerilerin geliştirilmesi amaçlanmaktadır.

- Aile ve Toplum: Çocuğun aile ve yaşadığı topluma ilişkin farkındalık kazandırma, ailenin ve toplumun bir bireyi olarak kendisine düşen görev ve sorumlulukları fark ettirme gibi becerilen kazandırılması amaçlanmaktadır.

- Güvenli ve Sağlıkıı Hayat: Bu yeterlik alanı ile çocuklara; sağlıklı yaşamak için yapılabilecekler, tehlike durumlarında yapılması gerekenler ile güvenli ve sağlıklı bir hayat için gerekli bilgi ve becerilerin kazandırılması amaçlanmaktadır. 
- Mesleki Gelişim: Mesleki gelişim alanı ile okul öncesi çağda çocukların mesleklerle ilgili kalıp yargılardan uzaklaşmaları ve mesleklere ilişkin olumlu tutum geliştirmeleri amaçlanmaktadır.

$\mathrm{Bu}$ eğitim programında verilen her bir yeterlik alanının ve her bir kazanımın devamında öğretmenlerin sınıf ortamlarında kazanımları kapsayıcı bir şekilde işleyebilmesi için açıklamalara ve kapsayıcı eğitimin veliyle işbirliği ilkesinden hareketle oluşturulan aile katılımı bölümlerine yer verilmiştir. Ayrıca verilen etkinlik örneklerinin kapsayııı bir şekilde işlenebilmesi için 'Etkinliğin Kapsayıcı Eğitime Uygun Olması Açısından Yapılan Öneriler 'alt başlığı oluşturulmuş, rehber niteliğinde önerilere yer verilmiştir. Aşağıda, üstte betimlenen yeterlik alanları ve kazanımları içeren bazı örnekler yer almaktadır.

Yeterlik Alanı: Okula ve Çevreye Uyum

\section{Kazanım No: 1}

Kazanım: Sinıf kurallarına uyar.

Açıklamalar: Öğrencinin sınıf kurallarının neler olduğunu bilmesi beklenmektedir. Bu kurallar sayesinde sınıfta geç öğrenen, engeli olan ya da üstün zekâlı olan bütün bireylerin eşit eğitim haklarına sahip olduğunun fark edilmesi beklenmektedir. Öğretmenlerin, sınıf kurallarını oluştururken tüm öğrencileri sürecin içerisine dâhil etmesinin kuralların öğrenciler tarafından benimsenmesine ve uyulmasına katkı sağlaması beklenmektedir.

\section{Kazanım No: 2}

Kazanım: Okula gidiş geliş yolunda gördüklerini söyler.

Açıklamalar: Çocuğun çevresini tanıması, çevresine karşı farkındalık geliştirmesi ve çevreye uyum sağlaması amacıyla okula geliş gidişlerde okul yolunda gördüklerini (bakkal, ağaç, market, oyun park1, karakol, fırın gibi) ifade etmesi beklenmektedir. Bu kazanımın farklı bağlamlarda ve bölgelerde (örn. kırsal ve kentsel bölgelerde yaşayan çocuklar) yaşayan çocukların yaşantılarına uyumlu bir şekilde ifade edilmesi beklenmektedir. Kazanıma yönelik uygulamalardan önce, ailelerden oryantasyon kapsamında çocuklarının okul yolundaki yerlerin isimlerini öğrenmeleri konusunda yardımcı olmaları istenebilir. Sınıfta görme engeli olan öğrenci olması durumunda ebeveynlerden destek talep edilebilir. Örneğin ebeveynlerden çocuğu okula getirirken gördüğü yerlerin isimlerini çocuğa söylemeleri ve belli aralıklarla tekrar etmesi istenebilir. Bu şekilde kazanım işlenirken görme engeli olan çocukların da derse katılması sağlanabilir.

\section{Yeterlik Alanı: Eğitsel Gelişim}

\section{Kazanım No: 3}

Kazanım: Bağımsız iş yapmanın önemini fark eder.

Açıklama: Çocuğun herhangi bir yetişkin müdahalesi olmaksızın bir işe başlama, o işi bitirme ve bağımsız iş yapmanın önemini fark etmesi beklenmektedir. Bu amaçla öğretmen tarafından çocuğa farklı görevler verilerek bağımsız iş yapmanın önemini fark etmesi sağlanır. Bu etkinlikten önce çocuk gelişimi ve eğitimine dair aile semineri verilmesi ve öğrencilerin neleri yapabileceği ve neleri yapabildiğinin bir ihtiyaç analizi yöntemiyle belirlenmesi önerilmektedir. Seminerlerde ailenin çocuğuna bağımsız bir 
şekilde iş yapabilmesi için fırsatlar sunması ve çocuğu cesaretlendirmesi gibi konularda öneriler sunulması önemlidir. Ailelere her çocuğun gelişim düzeyine uygun işler yapabileceği, çocuklarını kendilerine bağımlı bireyler olarak yetiştirmemeleri gerektiği vurgulanabilir. Buna ek olarak sınıfta engeli olan veya inisiyatif alma becerileri gelişime muhtaç olan çocukların tek başlarına herhangi bir iş yapamayacakları konusunda önyargı gelişebilmektedir. Etkinlikler ile öğrencilerin yetenek ve yeterlilik alanlarına uygun birtakım işler yapmasının sağlanması yoluyla önyargılar yok edilebilir. Bu durum, kendilerinin tek başına bir iş yapabildiklerini gören bireylerin de özgüven kazanmasına yol açabilmektedir.

\section{Yeterlik Alanı: Kendini Kabul}

\section{Kazanım No: 4}

Kazanım: Kendini tanıtan özellikleri bilir.

Açıklama: Bireyin kendisine ait kişisel özelliklerini (adı, soyadı, cinsiyeti, boyu, kilosu, ten rengi) fark etmesi ve bunları ifade etmesi beklenmektedir. Öğrencinin kendini tanıtırken ten rengini söylemesini beklemesi iki şekilde düşünülebilir. İlk olarak insanların farklı ten renklerine sahip olmasının doğal olduğunun öğrenciler tarafından fark edilmesinin sağlanması gerekmektedir. Bunun için de öğrencilerin kendini tanıtırken ten rengini de söyleyerek bunu normalleştirip öğrencilerin kendi ten renginden farklı bir renk gördüğü zaman şaşırmaması ve bunu doğal olarak karşılaması beklenmektedir. Ancak bu durum bazı toplumsal yargılardan dolayı sınıfta alay, lakap, dışlanma gibi sonuçlara da yol açabilmektedir. Öğretmenin kazanımı işlerken bu durumları göz önünde bulundurması ve gerekli hassasiyeti göstermesi beklenmektedir. Öğretmenlerin bu etkinliği uygulamadan önce insanların tenlerine ek olarak boylarının, kilolarının vb. kişisel özelliklerinin birbirinden farklı olabileceğini öğrencilere fark ettirmesi beklenmektedir. Bunun için bu kazanım verilmeden önce 'Farklı özelliklere sahip bireylere nasıl davranılması gerektiğine örnek verir 'kazanımının işlenmesi önerilmektedir.

\section{Kazanım No: 5}

Kazanım: Temel duyguların (mutlu, üzgün, kızgın, korku, şaşkınlık) dışındaki duyguların neler olduğunu söyler.

Açıklama: Bireylerin, kendini kabul ve ifade etmede, başkaları ile kurduğu ilişkilerde duygularını fark etmesi ve anlamlandırması iletişimini ve ilişkilerini güçlendirmektedir. Çocukların temel duyguların dışındaki duygularını fark etmeleri, bu farkındalığın iletişime ve ilişkilere yansıtılması çocukların kendilerini daha doğru ifade etmeleri ve başkalarını doğru anlamaları için bir temel oluşturmaktadır. Temel duyguların dışında şaşkınlık, kırgınlık, heyecan, öfke, gurur, alınganlık, hayranlık, hüzün, sevinç, şefkat vb. duygularının olduğunun bilmesi beklenmektedir. Öğretmenin kazanımı işlerken aşağıda yer alan kazanıma ait etkinliği (Duygular Dünyası) kullanması mümkün olabilir.

\section{Kazanım No: 6}

Kazanım: Kendinde gördüğü olumlu özellikleri fark eder/söyler.

Açıklama: Çocukların sahip olduğu yetenek, özellik, başarı ve yeterlilikleri (örn. yardımseverlik, paylaşımcılık, güzel konuşma, şarkı söyleme) fark etmesi, farkında olmadıkları özellikleri keşfetmeleri ve 
geliştirmeleri adına desteklenmesi beklenmektedir. Bu yönde yapılacak çalışmalar, çocuğun kendisi ile ilgili olumlu bir benlik algısı geliştirmesini ve grup içinde kendini rahat ifade etmesini sağlar. Her çocuğun mutlaka olumlu özellikleri vardır. Öğretmenlerin, çocukların bu özelliklerini fark etmeleri konusunda destekleyici olması beklenmektedir. Çocukların olumsuz özelliklerinden ziyade olumlu yönlerine odaklanılmalı, olumsuz özelliklerin neden olacağı sonuçların giderilmesi adına tedbirler alınmalıdır. Gerekli görüldüğü durumlarda okul rehber öğretmeni ile iletişime geçilerek aile yönlendirilmelidir.

Bu kazanım işlenirken her çocuğun mutlaka olumlu özelliklerinin olduğu bilinmelidir. Sınıf ortamında herhangi bir engel ile tanılanmış veya dezavantajlı koşullar içinde yaşayan bireylere karşı önyargı gelişmiş olabilir. Bu kazanımla önyargıların sona erdirilmesi de amaçlanmaktadır. Örneğin işitme engeli olan bir birey resim çizmede, görme engeli olan bir birey ise şarkı söylemede başarılı olabilir. Buna ek olarak bazı öğrencilerin katılım sağlama adına isteksiz olmaları durumunda öğretmenin bu çocukları ihmal etmeyip onları söz hakkı almaları için cesaretlendirmesi gerekmektedir. Her öğrencinin olumlu özelliklerinin ön plana çıkarılması, hem öğrencinin özgüveninin artmasına hem de diğer öğrencilerin arkadaşlarına karşı olumlu tutumlar geliştirmesine yol açabilir. Bu kazanımın edinilmesi için uygulanacak faaliyetler arasında öğretmenlerin öğrencilerini tanımaları adına çeşitli değerlendirme yöntemleri (ödev, tanıma fişi vb.) kullanması ve bu yolla öğrencilerinin olumlu yönlerini keşfetmesi yer alabilir.

\section{Programın Etkinlikleri}

Bu çalışmada MEB'in okul öncesi eğitim programında yer alan etkinliklerden üç tanesi seçilmiş ve bu etkinlikler kapsayıcı eğitime uygun hale getirilmeye çalışılmıştır. Bu etkinliklere bu çalışmada yer verilmesi, kapsayıcı eğitime uygun olmayan bariz yönlerinin olmasından kaynaklanmaktadır. Bu etkinliklerde kapsayıcı eğitim ile uyumlu olmayan bölümler yeniden düzenlenmiş; etkinliğin kapsayıcı eğitime uygun bir şekilde işlenebilmesi için ilgili yerlere notlar eklenmiştir.

MEB'in programında yer alan etkinlikler incelendiğinde, bu etkinliklerin sinıfta farklı özelliklere sahip (örn. herhangi bir engel ile tanılanmış olan, geç öğrenen, ana dili edinim düzeyi düşük olan, sosyoekonomik düzeyi düşük olan vb.) öğrenci ile nasıl uygulanabileceğine dair yeterli bilgi olmadığ1 anlaşılmaktadır. Yalnız bir etkinlikte işitme yetersizliği olan çocuklar için etkinliğin nasıl işlenmesi gerektiği ile ilgili bilgilere yer verilmiştir. Bu etkinlikler yeniden tasarlanırken etkinliklerin kapsayıcı eğitime uygun olarak işlenebilmesi adına hangi tedbirlerin alınması gerektiğine dair bilgilere yer verilmiştir.

Etkinliğin Adı: Duygular Dünyası

Yaş Grubu: 48 - 66 Ay

Yeterlik Alanı: Kendini Kabul

Kazanım: Temel duyguların (mutlu, üzgün, kızgın, korku, şaşkınlık) dışındaki duyguların neler olduğunu söyler. 


\section{Kazanım Numarası: 28}

Materyaller: Ek 1 (Temel Duygu Kartları) ve Ek 2 (Farklı Duygu İsimlerinin Listesi)

Ortam: Sinif Ortamı

\section{Etkinlik Süreci}

Çocukların daire/U düzeninde oturmaları sağlanır. Çocuklara aşağıdaki her bir temel duyguya ait örnek durum verilir. Çocuklara bireylerin farklı duyguları aynı anda yaşayabilecekleri gibi farklı duygulardan birini daha yoğun yaşayabilecekleri hatırlatılarak, her bir örnek olayın ardından yoğun olarak hangi duygunun yaşanabileceği sorulur. Ardından da o duygu kartı çocuklara gösterilir.

Eda'nın çok istediği bir oyuncak vardır. Akşam babası Eda'nın istediği oyuncağı alır getirir.

- Sizce Eda daha çok hangi duyguyu yaşar?

- Sizce Eda mutlu olmanın dışında böyle bir olay karşısında başka hangi duyguları hissediyor olabilir?

Deniz çikolatayı çok sevmektedir. Ama fazla yediğinde alerji olduğu için annesi yemesine müsaade etmez.

- Sizce Deniz en çok hangi duyguyu yaşar?

- Sizce Deniz üzgün olmanın dışında böyle bir olay karşısında başka hangi duyguları hissediyor olabilir?

Efe'nin çok sevdiği bir suluğu vardır. Arkadaşı Efe'den izin almadan suluğunu alır ve kırar.

- Sizce Efe en çok hangi duyguyu yaşar?

- Sizce Efe kızgın olmasının dışında böyle bir olay karşısında başka hangi duyguları hissediyor olabilir?

Miray, evde oyun oynarken bir anda anlam veremediği yüksek bir ses duyar.

- Sizce Miray en çok hangi duyguyu yaşar?

- Sizce Miray korkmuş olmasının dışında böyle bir olay karşısında başka hangi duyguları hissediyor olabilir?

Aşağıdakilere benzer sorular ile grup etkileşimi devam eder.

- Önceden duymadığınız ama bu etkinlik sırasında öğrendiğiniz duygular nelerdir? Tüm çocukların konuşmaları tamamlandıktan sonra, "mutluluk, üzüntü, kızgınlık, korku, şaşkınlık” gibi duyguların dışında farklı duyguların da olduğu ve bu duyguların neler olduğu tekrar hatırlatılarak etkinlik sonlandırılır.

\section{Etkinlikte Dikkat Edilmesi Gereken Durumlar}

- Temel duygulara ilişkin verilen örneklerde, çocuklar farklı duyguları ifade edebilir. Çocuklar, yazılanın dışında farklı bir duygu söylediğinde yargılanmamalıdır. "Böyle bir durumda böyle bir duygu yaşanır" gibi bir yönlendirmenin yapılması önerilmemektedir.

- Çocuklara bazı durumlarda aynı anda birden fazla duygunun yaşanabileceği hatırlatılabilir. Bireylerin kızgınlık duygusunu yaşarken aynı zamanda üzüntü duygusunu da yaşayabileceği ifade edilebilir.

- Çocuklara yoğun duygunun dışında başka hangi duyguların yaşanabileceği sorulduğunda öğretmen Ek 2'de yer alan duygu isimlerinden de faydalanarak kolaylaştırıcı bir rol üstlenebilir. 
- Çocukların duygulara dair ifade üretmede zorlandıklarının gözlemlendiği durumlarda çocuklar tahminde bulunmadan önce kendilerine duygu kartları gösterilerek "bunlardan hangisi daha çok hissediliyor olabilir" diye sorularla kolaylaştırıcı bir rol üstlenilebilir.

- Temel duygular ve bunların dışındaki duygulara ilişkin "duygu yumağı" adı verilen bir pano hazırlanıp, zaman zaman çocukların bu panodaki her bir duyguya ilişkin örnek vermeleri istenebilir.

\section{Etkinliğin Kapsayıcı Eğitime Uyumluluk Düzeyini Artırıcı Öneriler}

- Etkinlik sürecinde aile katılımının sağlanmasına önem verilmelidir. Okuryazar olmayan ya da konu hakkında fikri olmayan aileler olabileceği için etkinlikten önce ailelere yönelik bilgilendirme yapılabilir.

- Sınıfta görme zorluğu olan öğrenci olması durumunda duygu kartlarının daha büyük çıktılarının alınması ya da projeksiyon cihazı ile büyütülerek yansıtılması önerilmektedir. Tam görme kaybı olan öğrenci olması durumunda öğretmenin kartları gösterirken daha dikkatli olması ve belli tekrarlarla açıklama yapması önerilmektedir.

-Etkinlik esnasında özellikle görme ve işitme kaybı olan öğrencilerin faydalanabileceği ses ve görüntü kaydı alınması önerilmektedir. Böylece dersten sonra bu öğrenciler dersin tekrarını yapabilir ve ders esnasında dikkat etmediği bölümler üzerine odaklanabilir.

-Etkinlik sonunda değerlendirme soruları sorulurken tüm öğrencilerin katılımına özen gösterilmelidir. Öğretmen soru sorduğunda öğrencilere düşünme için zaman vermeli ve verilen yanıtlara dair dönüt verilmelidir.

\section{Aile Katılımı}

- Ailelerin, yaşanılan olaylar sonrasında duygularını doğru bir şekilde ve içtenlikle ifade ederek hem duygularını ifade edebilme becerileri ile ilgili hem de duyguları tanımalarına yönelik çocuklara model olmaları konusunda yönlendirilebilir.

- Ailelerin de evde çocukları ile duygu kartları aracılığı ile çeşitli faaliyetler gerçekleştirebilmeleri ve oyunlar oynamaları istenebilir.

\section{Değerlendirme}

Etkinlik sonunda çocuklara aşağıdakilere benzer sorular sorularak etkinliğe dair değerlendirme yapılabilir.

- Biz bu etkinlikte neler yaptık?

- Hangi duygu isimlerini öğrendiniz?

- Bu duygu isimlerinden hangilerini ilk defa duydunuz?

- Çocukların yaşadığı yoğun duygulara, başka hangi duygular eşlik etmiş olabilir?

Üstte yer alan sorulara ek olarak, öğrenci özellikleri ve ihtiyaçlarının gerektirebileceği alternatif ölçme ve değerlendirme yöntemleri kullanılabilir.

\section{Önerilen Diğer Etkinlikler}

Bazen çocuklar içlerine kapanabilir ya da konuşmak istemeyebilirler. Böyle durumlarda sınıftaki duygu yumağı panosu kullanılarak çocuklara 'Şu anda panodaki duygulardan daha çok hangisini yaşıyorsun?' gibi sorular sorulabilir. 
Etkinliğin Adı: Acil Numaralar

Yaş Grubu: 48-66

Yeterlik Alanı: Güvenli ve Sağlıklı Hayat

Kazanım: Acil durumlarda nerelerden ve kimlerden yardım alınabileceğini ifade eder.

Kazanım Numarası: 70

Materyaller: Ek 3 (Acil durumlarda başvurulabilecek kurumlar ve açılamaları) ve Ek 4 (İtfaiye, Polis, Ambulans resimleri)

Sözcükler - Kavramlar: Acil Durum

\section{Etkinlik Süreci}

Çocukların daire ya da U düzeninde oturmaları sağlanır. Öğretmen etkinliğin başında günlük yaşamda başlarına gelebilecek acil durumlarla ilgili örnekler verir. Duruma ilişkin sorular sorularak grup etkileşimine devam edilir.

Durum 1: 'Berk parkta neşe içinde oynarken parkın yakınındaki küçük kulübenin yandığını gördü. Kulübenin sahibi telaşla kulübenin yanında dolaşıyordu.'

Sizce böyle bir durumda kulübe sahibi kimlerden/nerelerden yardım alabilir?

Sizce böyle bir durumda Berk ve çevresindeki kişiler kimlerden/nerelerden yardım alabilir?

Çocuklar dinlenir ve cevapları alınır. Öğretmen çocuklara Ek 3’te Durum 1 ile ilgili açıklamaları yapar.

Durum 2: 'Berk annesiyle yolda giderken bir adamın hızla yanından geçtiğini gördü. Biraz daha ilerleyince yaşlı bir teyzenin üzüntüyle 'Çantamı çaldılar!' diyerek bağırdığını duydu.'

Sizce öyle bir durumda yaşlı teyze kimlerden/nerelerden yardım alabilir?

Sizce öyle bir durumda Berk ve annesi kimlerden/nerelerden yardım alabilir?

Çocuklar dinlenir ve cevapları alınır. Öğretmen çocuklara Ek 3’te Durum 2 ile ilgili açıklamaları yapar.

Durum 3: 'Berk annesiyle evde otururken bir ses duydu. Merakla balkona çıııp baktıklarında Sevgi'nin bisikletten düştügünü ve bacağını acıyla tuttuğunu gördüler. Berk'in annesi Sevgi’nin bacağının kırılmış olabileceğini söyledi.'

Sizce Berk ve annesi kimlerden/nerelerden yardım alabilir?

Çevrede olayı gören başka kişiler varsa kimlerden/nerelerden yardım alabilir?

Çocuklar dinlenir ve cevapları alınır. Öğretmen çocuklara Ek 3’te Durum 3 ile ilgili açıklamaları yapar. Öğretmen elindeki İTFAIIYE resmini gösterip yüksek sesle 'Yangın var; 110 İtfaiye!' diyerek itfaiye grubunun yanına gelmesini sağlar. Etkinliğin diğer sürecine geçilir. Öğretmen önceden hazırladığı '1.2.0.5' rakamlarından oluşan kartları çocuklara gösterir. Çocuklardan bu kartlarla, itfaiye, polis ve ambulans resimlerini gösterdiğinde telefon numaraları oluşturmalarını ister. Aralarından istekli olanlara ise oluşturdukları bu numaraları panoya yapıştırmasını söyler. Etkinlik sonlandırılırken, çocuklara onları üzebilecek başka durumlar olduğunda çevrelerindeki kişilerden, okulda ise öğretmenlerden, rehber öğretmenlerden, okul idarecilerinden ve diğer okul çalışanlarından yardım alabilecekleri söylenir.

\section{Etkinlikte Dikkat Edilmesi Gereken Durumlar}


Çocuklara gösterilen resimler aile katılımının sağlanması adına evde boyama ödevi olarak gerçekleştirilebilir. Öğretmenin sınıfta etkinlik sırasında göstereceği resimlerin önceden boyanması sağlanabilir.

Daha önce durumlarda anlatılanlara benzer travmatik yaşantısı olan çocuklar olabilir. Çalışmalar sırasında olumsuz yaşantısı olduğu fark edilen çocuklar ile ilgili rehber öğretmen ile işbirliği içerisinde destekleyici çalışmaların yapılması önerilmektedir.

\section{Etkinliğin Kapsayıcı Eğitime Uyumluluk Düzeyini Artırıcı Öneriler}

Sınıfta görme kaybı yaşayan öğrenci olması durumunda resimlerinin büyük şekiller olarak hazırlanmasına dikkat edilmelidir. Öğretmen 1,0,2,5,6 rakamlarından oluşan kartları az gören öğrencinin de görebileceği boyutta oluşturmalıdır. Ayrıca bu rakamları projeksiyon cihazı yoluyla duvara yansıtması az gören öğrenci için daha faydalı olacaktır.

Tam görme kaybı yaşayan öğrenci varsa resimlerin kabartmalı olarak verilip boyanması istenebilir. Dahası, araba resimleri öğretmen tarafından silikonla çizildikten sonra öğrenciye verilebilir. Öğrencinin bu şekilde elleriyle şekli tanıyabilmesi ve boyama yapabilmesi sağlanabilir.

Sınıfta öğrenmede güçlük yaşayan öğrencilerin etkinlik sürecine dâhil edilmesi ve kendilerini ifade etmeleri adına cesaretlendirilmeleri gerekmektedir.

Etkinlik sonunda değerlendirme soruları sorulurken tüm öğrencilerin katılımına özen gösterilmelidir. Öğretmen soru sorduğunda öğrencilere düşünme için zaman vermeli ve cevaplara dair gerektiğinde dönüt vermelidir.

Etkinlikte 'şiddet 'kavramı geçmektedir. Her öğrencinin bilişsel gelişim düzeyi ve deneyimleri farklı olduğundan bu kavram öğrenciler için farklı şekillerde tanınabilir. Dolayısıyla etkinlikten önce 'şiddet ' kavramının tanımının ve açıklamasının geniş bir kapsamda yapılması önerilmektedir.

\section{Aile Katılımı}

Etkinlik sürecinde ve sonrasında ailelerden çocuklarının acil durumlarda ulaşabilecekleri numaraları beslenme çantaları, künyeleri, çantaları vb. yerlere koymaları istenebilir.

Çocukların aile tarafından acil durumlarda anne, baba, veli dışında kimlerden yardım alabileceğine ilişkin bilgilendirilmeleri istenebilir.

Çalışma sırasında kullanılan resimler boyama sayfaları halinde eve gönderilerek ailelerle birlikte boyama yapilmas1 istenebilir.

\section{Değerlendirme}

Etkinlik sonunda çocuklara aşağıdakilere benzer sorular sorularak etkinliğe dair değerlendirme yapılabilir.

Acil durumlarda nerelerden yardım alabilirsiniz?

Yardım alabileceğiniz yerlerin telefon numaraları nedir?

Çevrenizde başka kimlerden yardım alabilirsiniz?

Üstte yer alan sorulara ek olarak, öğrenci özellikleri ve ihtiyaçlarının gerektirebileceği alternatif ölçme ve değerlendirme yöntemleri kullanılabilir. 


\section{Okul Öncesi Eğitim Kapsayıcı Rehberlik Programı'nın Ölçme ve Değerlendirme Yaklaşımı}

Okul rehberlik ve psikolojik danışmanlık hizmetleri, kapsamı gereği bireylerin duyuşsal alanlarına hizmet eden psikolojik bir içeriğe sahiptir. Okul öncesi eğitimde rehberlik programı da okul rehberlik ve psikolojik danışmanlık hizmetlerinin bir parçası olarak benzer özelliklere sahiptir. Programda yer alan kazanımların gerçekleşmesi süreç gerektirmektedir. Bazı çocuklar, yapılan çalışmaların ardından kazanımları elde edebilirken, bazı çocukların kazanımları edinmesi daha uzun bir süreç gerektirebilmektedir. Kazanımların tutum, beğeni, duygu gibi özellikleri içermesi ve çocukların gelişim özellikleri ve hızlarındaki farklılıklar, kazanımlarda objektif göstergelerin bulunma ve ölçülmesinde bazı zorlukların yaşanmasına neden olabilmektedir. Bu durum, daha kapsayıcı, öğrencilere göre uyarlanabilen ve düzenlenebilen ölçme ve değerlendirme yöntem ve süreçlerinin benimsenmesini gerektirmektedir.

Bu programda kapsayıcı eğitimin ölçme ve değerlendirme ilkelerinden olan ve eğitim sürecinin genellikle başında gerçekleştirilen tanılayıcı ölçme ve değerlendirme işlemi Ek 5 ve Ek 6' da yer alan örnek sorular gibi sorularla uygulanabilmektedir. Sorular veli ve öğretmen işbirliği içinde cevaplandırılıp öğrencilere eğitim verilmeden önce öğrencilerin ne bildiği saptanıp öğrenciye göre eğitim verilebilmesi sağlanabilmektedir. Ayrıca her etkinliğin sonunda değerlendirme soruları yer almakta olup bu sorular öğretmenler tarafından etkinlik sonrası veya eğitim öğretim dönemi sonunda öğrencilere uygulanabilmektedir. Bu şekilde her etkinlik sonrası anlık olarak sınıf ortamında verilen bilgilerin hangi öğrenciler tarafından anlaşıldığı da belirlenebilmektedir. Bu değerlendirmeler öğrencilere sayısal skorlar tayin etmek veya onları rekabet içine sokmak amacıyla değil, öğrencilerin güçlü ve zayıf yönleri hakkında bilgi vermek ve daha iyi öğrenmeleri için onlara yol göstermek amacıyla yapılmalıdır.

Okul Öncesi Eğitim Rehberlik Programı’nda Ölçme ve Değerlendirme İhtiyaç Analizi ve Gözlem Formları

Kapsayıcı eğitim, ölçme ve değerlendirme süreçlerinin ve araçlarının öğrencilerin tanılanarak ayrıştırılması yoluyla kullanılmasını reddetmekte, bu süreçlerin ve araçların öğrencilerin eğitsel ihtiyaçlarının belirlenmesi ve öğrenme süreçlerinin takip edilmesi amacıyla kullanılmasını önermektedir. İhtiyaç analizi, öğrencilerin eğitsel ihtiyaçlarının belirlenerek eğitim sürecinden azami düzeyde faydalanmaları adına gerçekleştirilen bir ölçme ve değerlendirme sürecidir. Bu çalışmada tasarlanan program kapsamında ihtiyaç analizi yapılması öngörülmüş; uygun kazanımların belirlenebilmesi ve bunların edinilebilmesi adına eğitim öğretim yılı başında çocukların rehberlik ile ilgili ihtiyaçlarının neler olduğunun belirlenmesi için çeşitli formlar geliştirilmiştir (Ek 5). İhtiyaç analizi formları anne-baba ve öğretmenlere uygulanmak üzere ayrı ayrı hazırlanarak uygulanabilmekte, bu formların hazırlanmasında kazanımlardan yararlanılabilmektedir.

Hazırlanan ihtiyaç analizi formu, öğretmenler tarafından yıl içinde hedeflenen kazanımlara ve olası diğer faktörlere göre yeniden düzenlenebilir. Bu formun veliler ve öğretmenler tarafindan doldurularak verilerin kıyaslamalı bir yöntem ile analiz edilmesi gerekmektedir. Aynı form, süreç sonunda öğrencilerin kazanımları gerçekleşme düzeyini belirlemek için de kullanılabilmektedir. 
Tasarlanan kapsayıcı programda okul öncesi eğitimde rehberlik programı uygulamalarında yer alan kazanımların çocuklar tarafından ne düzeyde edinildiğine ilişkin tanımlanacak göstergelere dayalı yapılandırılmış gözlem formu düzenlenmiştir (Ek 6). Bu formlar, öğretmenlerin çocukları daha sistemli bir şekilde gözlemlemelerine firsat sunmaktadır. $\mathrm{Bu}$ formlar etkinlik sonrası uygulanmak üzere hazırlanabilecekken, eğitim-öğretim dönemi sonunda da uygulanabilir. Alınacak sonuçlar çocuklar hakkında veri sağlarken aynı zamanda çocukların rehberlik ihtiyaçlarının belirlenmesine de kaynaklık edebilmektedir. Ek 6, öğretmenler için hazırlanmış örnek gözlem formu olarak değerlendirilebilir.

Tasarlanan programda gözlem formu gösterge yazılabilecek kazanımlardan birinin etkinliği için örnek olarak hazırlanmıştır. Uygun olan diğer kazanımların etkinlik sonrasında da kullanılması için benzer formlar hazırlanabilir.

\section{Kapsayıcı Rehberlik Programında Kazanım Ediniminin Değerlendirilmesi}

Program çerçevesinde kazandırılmak istenen kazanımların gerçekleşmesi rehberlik hizmetlerinin doğası gereği kısa, orta ve uzun vadede gerçekleşebilir. Dolayısı ile bazı kazanımlara ve yeterliklere ulaşılıp ulaşılmadığının gözlenmesi de zaman alabilir.

\section{Kazanımların Kısa Vadede Edinilme Düzeyinin Değerlendirilmesi}

Kazanımlara kısa vadede ulaşma durumunu değerlendirme, gerçekleştirilen her etkinliğin ardından gerçekleştirilmesi öngörülen bir süreçtir. Çocuklara yönelik yapılacak bu değerlendirmede birtakım yansıtma ve değerlendirme sorularının açık uçlu bir şekilde hazırlanarak sorulması mümkün olabilmektedir. Popham'e (1999) göre açık uçlu sorular, eğitimin değerlendirilmesi sürecinde öğrencilerin yaratıcı düşünme, eleştirel düşünme, problem çözme, karar verme, analiz ve yaratıc1lık gibi üst düzey zihinsel becerilerini ölçmede etkili bir araç olarak kullanılabilmektedir. Bu tip sorularda cevabın içeriği, niteliği ve uzunluğu açısından cevaplayıcı özerk bir role sahiptir.

Yansıtma Soruları: Etkinliklerin uygulanması sürecinin sonunda çocukların, kazanımın gerçekleşmesinde rol oynayan ve kendisinden kaynaklanan etkenler üzerinde düşündürülmesi önemli olarak değerlendirilmektedir. Etkinlikte ulaşılması istenen temel amaçlara dair çocukların 'Bu hikâyenin en çok sevdiğin bölümü neresiydi?' ve 'Bu etkinlikte en çok neleri sevdin?' gibi sorular yoluyla düşünmesi sağlanabilir. Bu gibi soruların değerlendirme sorularından farkı, yanıtın çocuğa özel olması ve bir doğru ya da yanlışın olmamasıdır. Öğretmenlerin, çocukların bu tür sorulara verdikleri cevaplardan, özellikle çocuğun gelişimine katkı sağlayan olumlu cevaplara odaklanmaları ve çocuğun dikkatini çekecek biçimde bu olumlu etkenler hakkında çocuğa geri bildirim vermesi yerinde olacaktır. Bu durumun, çocuğun gelişimine katkı sağlayacağına inanılmaktadır.

Değerlendirme Soruları: Değerlendirme sorularının amacı, çocukların kendilerine kazandırılması amaçlanan kazanımlar hakkında ne düzeyde bilgi sahibi olduklarının ve bu bilgilerin gerçek yaşam durumlarında ne düzeyde kullanılabildiğinin belirlenmesidir. $\mathrm{Bu}$ sorular, çocuklara etkinliğin gerçekleştirilmesi sırasında sorulabileceği gibi etkinliğin bitiminde de sorulabilir. Öğretmenler de benzer değerlendirme soruları üretebilir ve bunları izleme amaçlı sorabilir. 
Değerlendirme sorularından elde edilen cevaplara ilişkin görüşler, çocuk hakkında bir yargı içermekten çok, çocuğun ilgili beceriyi istenen nitelikler açısından hangi düzeyde öğrenebildiği ve günlük yaşamla ne kadar ilişkilendirebildiğine odaklanmalıdır. Mullis, Martin, Gonzales ve Kennedy’e (2003) göre, değerlendirme soruları hazırlanırken basitten karmaşığa dört aşamalı bilişsel bir sınıflama kullanılmıştır. Birinci düzeyde etkinlikte açıç̧a yer alan düşünceleri bulma ve doğrudan çıkarım yapma amaçlanmaktadır (Örn. 'Sabah tanıdığımız bir kişiyle karşılaştığımızda ona öncelikle ne söyleriz?’). İkinci düzeyde ise etkinlikte açıkça yer almayan düşünceleri bulma ve yorumlama amaçlanmaktadır (Örn. 'Sabah, akşam ya da gece yatarken verilen selamların benzer ve farklı yönleri nelerdir?'). Üçüncü düzeyde temel amaç, etkinlikte geçen olayları kişisel bilgi ve deneyimlerle ilişkilendirmek ve bilgileri güncel yaşamla uyumlu hale getirmektir. (Örn. 'Bu etkinlikte öğrendiklerini düşün. Öğrendiğin her bir selamlaşma için evde ve okulda yaşananlardan örnekler verir misin?’). Dördüncü düzeyde ise amaç, etkinliğin içeriğini eleştirmek ve değerlendirmektir (Örn. 'Can, sabah okula gidiyordu. Arkadaşı Ayşe ile karşılaştı. Suratı asık biçimde Ayşe’ye günaydın dedi. Bu örnekte Can'ın doğru ve yanlış yaptığı davranış nedir? Neden?').

\section{Kazanımların Orta Vadede Edinilme Düzeyinin Değerlendirilmesi}

Kazanımların orta vadede edinilme durumunu değerlendirme, Okul öncesi eğitimde rehberlik programının uygulandığ1 eğitim-öğretim döneminde ya da eğitim öğretim yılı sonunda yapılır. $\mathrm{Bu}$ tür değerlendirmelerde, yaş gruplarına uygun olarak seçilen kazanımlar dikkate alınarak, hazırlanacak kazanım kontrol listeleri ya da gözlem formlarının uygulaması yapılabilir. Ayrıca burada elde edilecek verilerle okul öncesi çocuğunun daha önceki yaş grubunda seçilen kazanımlara ilişkin kazanım kontrol listesinin karşılaştırması çocuğun gelişimi hakkında da veri sağlayabilmektedir.

\section{Kazanımların Uzun Vadede Edinilme Düzeyinin Değerlendirilmesi}

Kazanımların uzun vadede edinilme düzeyinin değerlendirilmesinin çocuğun okul öncesi eğitim sürecini tamamladıktan sonraki süreçte yapılması öngörülmektedir. Bu değerlendirmelere temel oluşturacak veriler testler, görüşmeler, gözlem kayıtları ve ilgili gelişim araçları yoluyla toplanabilmektedir.

\section{Ölçme ve Değerlendirme Sonucunda Toplanan Bilgilerin Yönetilmesi}

Okul rehberlik ve danışmanlık hizmetleri kapsamında ölçme ve değerlendirme amacıyla öğretmenin uygulayacağı ölçme araçları arasında gelişim ve gözlem formları kullanılabileceği gibi çocuk hakkında veri elde edilecek başka ölçme ve değerlendirme araçları da kullanılabilmektedir. Bunların arasında okul rehberlik birimlerinin kullanabileceği standart testler (GEÇDA, DENVER II, AGTE, gibi) bulunmaktadır. Ölçme ve değerlendirme uygulamalarının kim tarafından gerçekleştirildiğine bakılmaksızın (örn. sınıf öğretmeni veya psikolojik danışman) çocukların özel yaşamını etkileyeceği düşünülen, çocuğun ruh sağlığının korunması açısından önemli olan, paylaşılması durumunda çocuğa zarar vereceği düşünülen bilgiler okul rehber öğretmeni ile iş birliği içinde dikkate alınması ve gizliliğin sağlanması gereklidir (Erkan, 2006). Hangi türden olursa olsun değerlendirme işleminin yapılış nedeni kişisel merakın tatmini değil elde edilen verilerin yorumlanarak, gerekli önlemlerin alınmasıdır. 
Okul öncesi eğitim kurumlarında, çocuklara yönelik gerçekleştirilen her türlü ölçme ve değerlendirme işleminin sonuçlarının çocuklar için tutulan dosyalarda bulundurulması çocuğun yönlendirilmesinde ve gelişiminin desteklenmesi sürecinde önemli olacaktır. Dahası gerçekleştirilen ölçme ve değerlendirme süreçlerinin sonucunda verilen kararların öğrencilerin etiketlenerek çeşitli sınıflara ayrılması sonucuna yol açmaması, sadece öğrenciler için uygun müdahaleler planlanması için kullanılması gerekmektedir.

\section{Rehberlik Hizmetleri Kapsamında Ölçme ve Değerlendirmeye İlişkin Müşavirlik}

Kapsayıcı eğitimin temel öngörülerinden biri, tüm ölçme ve değerlendirme süreçlerinde ilgili paydaşların işbirliği yoluyla sürece katılarak verilen kararlara katkı sunmalarının sağlanmasıdır. Okul öncesi eğitimde rehberlik programı kapsamında kullanılacak tüm ölçme ve değerlendirme araçlarının seçilmesinde, hazırlanmasında ve kullanılmasında okul rehber öğretmeninin müşavirliğinden yararlanılması, ilgili öğretmenlerin ve aile bireylerinin desteğinin sağlanması oldukça önemlidir.

Bazı ölçme ve değerlendirme araçlarının kullanılması, sonuçlarının değerlendirilmesi ve gerekli yönlendirmelerin yapılması uzmanlık gerektirmektedir. Okul rehber öğretmenleri ya da Rehberlik ve Araştırma Merkezlerinde (RAM) görev yapan uzmanlar tarafından çocukların gelişim düzeylerini değerlendirmek amaciyla uygulamalar gerçekleştirilmektedir. Öğretmenin, okul rehber öğretmeni ya da RAM ile işbirliği içinde ölçme ve değerlendirme sürecini gerçekleştirmesi çocuğun gelişimini desteklemek için yararlı olacaktır.

Kapsayıcı eğitimin diğer bir öngörüsü, sonuç kadar eğitim süreçlerine ve bu süreçlerde öğrencilerin edindikleri faydalara odaklanılmasıdır. Dolayısıyla kazanımların değerlendirilmesinin süreç ağırlıklı olması öngörülmektedir. Ayrıca kapsayıcı eğitimin öngörülerine göre eğitim süreçleri başlamadan öğrenci ihtiyaçlarının ve gelişim düzeyinin belirlenmesi adına birtakım ölçme ve değerlendirme işlemleri yapılabilir. Bunun için hazırlanan kazanım formları sene başında, sene içinde ve sene sonunda öğrencilere uygulanmalidır.

Rehberlik ile ilgili kazanımların bir kısmı bir ders saatinde edinilebilecek düzeyde ve nitelikte olmayabilir. Bazı kazanımlar bir olgunlaşma süreci gerektirmektedir. Bazı kazanımlar gözlem yoluyla değerlendirilebilirken, bazıları için birtakım standart ölçme araçlarının kullanılması gerekebilir. Dolayısıyla ölçme ve değerlendirme işlemlerinin sürece yayılması doğru ölçme ve değerlendirme yapma adına gerekli olabilir. Bu süreç içerisinde öğrenciler değerlendirilirken kapsayıcı eğitimin eşitlik (tüm öğrencilerin adil şartlarda değerlendirmeye alınması), kültüre duyarlılık (değerlendirme araçlarında farklı grupların kültürleriyle ilgili içerikler kullanılması, kültürel hassasiyet gösterilmesi, ırkçılıktan uzak durulması), tamamlayıcılık (puanlama yapılmaması, süreç odaklı ve biçimlendirici olması), farklılaştırılmışlık (öğrencinin ihtiyacına göre paralel çeviri, otomatik işaretleme, büyük puntolu sınav, kulaklık kullanımına izin verme), otantiklik (gerçek yaşamla bağlantılı olması) ve demokratiklik (öğrencinin kendi kendini ve akranlarını değerlendirerek sorumluluk alması) gibi ilkeleri dikkate alınarak süreç yürütülmelidir (Taneri, 2019). Bu bağlamda öğretmenlerin değerlendirme yaparken sınıf ortamında 
demokratik bir ortam hazırlayıp engeli olan bireyleri, farklı ana dile sahip olan öğrencileri, göçmenleri, geç öğrenen öğrencileri ihmal etmeden bireyselleştirilmiş bir süreç hazırlaması gerekebilmektedir.

\section{Kapsayıcı Rehberlik Programının Özgünlüğü, Felsefesi ve Önemi}

Okul öncesi eğitime başlamak çocukların hayatlarındaki en önemli dönüm noktalarından birisidir. $\mathrm{Bu}$ dönemde çocuklar ilk kez evden ayrılmakta, farklı bir ortama girip o ortamda arkadaşlar edinmekte ve programlı bir öğretimde eğitim almaktadır. Tüm bu yaşantılar, çocukların sosyal, duygusal ve akademik gelişimleri adına önem teşkil etmektedir. Okul öncesi eğitimde nitelikli ve çeşitli yöntem ve tekniklerin kullanıldığı bir ortamda eğitim alan, öğrenme ve gelişim açısından iyi bir temele sahip çocukların gelecekte bireysel, eğitsel ve mesleki yaşamlarının da olumlu yönde gelişeceği öngörülmektedir (Erkan \& Kırca, 2010). Bu çalışmada yeniden tasarımı yapılan okul öncesi rehberlik programının okul öncesi eğitimin zengin bir program içeriği ile tüm öğrencileri kapsayacak bir süreç içerisinde verilmesini sağlamaktadır. Ayrıca program, öğretmenlerin eğitim ortamlarında tüm öğrencilere hitap edebilmesi için kapsayıcı ilke ve uygulamalara dayandırılmaktadır.

MEB'in yayınlamış olduğu okul öncesi eğitim rehberlik programı incelendiğinde bu programda yer alan etkinliklerin ve kazanımların programın genel çocuk evrenine hitap ederken bireysel özellikleri ve ihtiyaçları farklı olabilecek bireyleri yeterince dikkate almadığı, engeli olan veya geç öğrenen bireylere, okuryazar olmayan ya da resmî dili öğrenme açısından yavaşlık yaşayan bireyleri daha çok kapsamaya ihtiyaç duyduğu görülmektedir. Bu nedenle bu çalışmada Milli Eğitim Bakanlığının yayınlamış olduğu okul öncesi eğitim rehberlik programı kapsayıcı eğitime uygun hale getirilmesi amaçlanmıştır. Bu amaçla programda yer alan yeterlik alanları, kazanımlar ve etkinlikler tek tek incelenmiş; örnek olması açısından toplamda altı kazanım ve iki etkinlik çalışmaya dâhil edilmiş ve bunlardan her birinin kapsayıcı eğitime uygun hale getirilmesi için gerekli düzenlemeler yapılmıştır. Bu şekilde sınıfında herhangi bir engel ile tanılanan, geç öğrenen, ebeveynleri okuryazar olmayan, dil gelişimi açısından zorluk yaşayan bireylerin de yapılan etkinliklere katılması ve bu etkinliklerden en üst düzeyde verim alması amaçlanmıştır.

Rehberlik programı hazırlanırken kapsayıcı eğitimin özellikle herkes için eğitim ilkesinin göz önünde bulundurulması önem arz etmektedir. Yani rehberlik programlarının eğitim dilini öğrenmede güçlük yaşayan, farklı inanca mensup olan, herhangi bir engeli olan, sosyoekonomik düzeyi yetersiz olan, kırsal kesimde yaşayan veya velisi okuryazar olmayan bireyleri de kapsaması gerekmektedir. Ayrıca kapsayıcı bir şekilde oluşturulan rehberlik programlarının kazanımlarının öğrencilere aktarılması da önemlidir. Bu bakımdan okul rehber öğretmenleri ve psikolojik danışmanların ve branş öğretmenlerinin kazanımları öğrencilere aktarırken kapsayıcı eğitimin ilkeleri, felsefesi ve amaçları hakkında fikir sahibi olması gerekmektedir.

\section{Sonuç ve Öneriler}

Kapsayıcı eğitim dersi 2018 yılında eğitim fakültelerinde seçmeli ders olarak okutulmaya başlanmıştır. Bu durum önemli olmakla birlikte kapsayıcı eğitim dersinin zorunlu hale getirilmesinin daha faydalı olacağı düşünülmektedir (Koçyiğit \& Şimşek, 2019). Çünkü hâlihazırda çalışan öğretmenlerin önemli bir kısmının 
kapsayıcı eğitim hakkında herhangi bir resmî eğitim sürecinden geçmedikleri için bu konuya dair fikir sahibi olmadıkları bilinmektedir. Bu kapsamda MEB tarafından kapsayıcı eğitimle ilgili hizmet içi eğitim seminerleri düzenlenip mevcut öğretmenlerin kapsayıcı eğitim hakkında fikir sahibi olmaları sağlanabilir.

Öğretmenlerin kazanımları işlerken sınıf ortamında bulunan her öğrencinin gelişim seviyesinin, ana dilinin, maddi durumunun, velisinin ona gösterdiği ilginin aynı olmadığını bilmesi gerekmektedir. Farklı özellikleri olan öğrencilerin de sınıf ortamında bulunabileceği unutulmamalı, öğretmenlerin bu öğrencilere karşı farklı davranışlar sergilememesi, her öğrenciye davrandığı gibi davranması ve sınıfta bulunan öğrencilere de insanların birbirilerinden farklı olabileceğinin doğal karşılanması gerektiği vurgulanmalıdır. Bu şekilde davranılması sonucunda sınıf ortamında farklılıklara saygı duyulması ve tüm öğrencilerin öğrenme sürecine aktif bir şekilde katılması sağlanabilir.

Öğretmenlerin ölçme ve değerlendirme sürecine süreç odaklı yaklaşması, eğitim süreçlerinin çeşitli aşamalarında ölçme ve değerlendirme yaptıktan sonra süreç içerisinde not vermeden, öğrencileri rekabet içine sokmadan, her öğrencinin farklı bilişsel ve duyuşsal becerilere sahip olduğunu bilerek davranmaları oldukça önemlidir. Öğretmenlerin ölçme işlemini yaparken sınıfında engel ile tanılanmış bireyler olması durumunda ölçme aracını bu bireylere göre uyarlaması beklenmektedir. Örneğin görme kaybı olan bireyler için sınav kâğıdının büyük karakterler ile hazırlanması, kulaklık kullanımına izin verilmesi veya Braille alfabesiyle sınavın yapılması; işitme engeli olan bireyler için ise sınavların görsel duyulara dayalı olarak yapılması iyi uygulamalar arasında gösterilebilir.

Okul psikolojik danışmanları ve ilgili uygulayıcılar, öğrenme kazanımlarını işlerken süreç öncesinde öğrencilerin hazırbulunuşluk düzeylerini dikkate almalı, her öğrencinin belirlenen standart kazanımları elde edebilecek bilişsel, duyuşsal ve psikomotor yeterlik düzeyine sahip olamayacağını unutmamalıdır. Bu amaçla programda her bir öğrenciye uygun kazanımlar belirlenmeli ve bu kazanımların elde edilmesi hedeflenmelidir. Ayrıca psikolojik danışman ve rehber öğretmenler süreç içerisinde çevre ve veliyle işbirliği içerisinde olmalı, her velinin farklı bilişsel becerilere ve deneyimlere sahip olduğunu unutmamalı ve gerekli durumlarda velilere kazanımlarla ilgili seminerler düzenlemelidir. Rehber öğretmenler öğrencilerin ve velilerin ihtiyaçlarına, sosyoekonomik durumlarına ve demografik özelliklerine; çalıştıkları okulun ise bulunduğu konuma (köy okulu veya merkez okul) göre kazanımlarda ve etkinliklerde uyarlamalar ve düzenlemeler yapmalı, kazanımları ve etkinlikleri her öğrencinin en üst düzeyde faydalanacağı şekilde oluşturmalıdır.

Öğretmenler tarafından uygulanabilecek kapsayıcı bir rehberlik programının tasarımı için (i) öğretmenlere kapsayıcı eğitimin ilkelerini hayata geçirmeleri adına kapsayıcı eğitimin ne olduğu ve gereklilikleri ile ilgili hizmet içi eğitimler verilmesi; (ii) kapsayıcı eğitimin uygulanması için öğretmenlere gerekli motivasyonun sağlanması; (iii) öğretmenlerin öğrencileriyle olumlu ilişkiler geliştirmesi, (iv) öğrencilerin okula aidiyet duygusunu geliştirmelerinin sağlanması ve (v) her öğrencinin birbirinden farklı olduğunun bilinmesi gerekmektedir. 


\section{Kaynaklar}

Başal, H. A., \& Kahraman, P. B. (2019). Köyde ve kentte yaşayan annelerin okul öncesi eğitim kurumlarından beklentileri. Mehmet Akif Ersoy Üniversitesi Eğitim Fakültesi Dergisi, (47), 38-56.

Booth, T., \& Ainscow, M. (2002). Index for inclusion: Developing learning and participation in schools. Bristol: Center for Studies on Inclusive Education.

Carr, A. (2009). What works with children, adolescents, and adults? A review of the effectiveness of psychotherapy. Routledge.

Cole, R. W. (2008). Educating everbody's children. Diverse teaching strategies for diverse learners. Alexandria, VA: ASCD.

Çelik, R. (2017). Adalet, kapsayıcıllk ve eğitimde hakkaniyetli fırsat eşitliği. Fe Dergi, 9(2), 17-29.

National Institute of Mental Health. (2018, July). Anxiety disorders. U.S. Department of Health and Human Services, National Institutes of Health. https://www.nimh.nih.gov/health/topics/anxietydisorders/index.shtml

Eğitim Reformu Girişimi (2016a, Temmuz). Türkiye ’de ortaöğretimde kapsayıcı eğitim durum analizi, http://www.egitimreformugirisimi.org/wpcontent/uploads/2017/03/ERG_KapsayiciEgitim_Durum Analizi.pdf .

Eğitim Reformu Girişimi (2016b, Temmuz). Türkiye ’de kapsayıcı eğitimi yaygınlaştırmak için politika önerileri. http://www.egitimreformugirisimi.org/wpcontent/uploads/2017/03/ERG_KapsayiciEgiti m_PolitikaOnerileri.pdf .

Erkan, S. (2006). Okul psikolojik danışma ve rehberlik programlarının hazırlanması. Nobel Yayıncılık.

Erkan, S., \& Kırca, A. (2010). Okul öncesi eğitimin ilköğretim birinci sınıf öğrencilerinin okula hazır bulunuşluklarına etkisinin incelenmesi. Hacettepe Üniversitesi Ĕgitim Fakültesi Dergisi, 38, 94106.

Koçyiğit, E., \& Şimşek, H. (2019). Kapsayıcı eğitim bağlamında Türkiye'de ortaöğretim programlarında çokkültürlülüğün izleri. Kuram ve Uygulamada Sosyal Bilimler Dergisi, 3(2), 75-90.

Kourkoutas, E. E., \& Xavier, M. R. (2010). Counseling children at risk in a resilient contextual perspective: A paradigmatic shift of school psychologists 'role in inclusive education. Procedia Social and Behavioral Sciences, 5, 1210-1219.

MEB. (2013). Okul öncesi eğitimi programı. Milli Eğitim Bakanlığı

MEB. (2012). Okul öncesi eğitim rehberlik programı. Milli Ĕ̆itim Bakanlı̆̆ı

Melhuish, E. C. (2011). Preschool matters. Science, 333(6040), 299-300.

Özdaş, F. 2019). Kapsayıcı Eğitim Programları ve Göçmenler. Sakız H. ve Apak H. Türkiye 'de Göçmen Kapsayıcıllğı: Sorundan Fırsata Dönüşüm Önerileri. (ss. 165- 185). Pegem Akademi.

Sakız, H., Woods, C., Sart, H., Erşahin, Z., Aftab, R., Koç, N., \& Sarıçam, H. (2015). The route to 'inclusive counselling': Counsellors' perceptions of disability inclusion in Turkey. International Journal of Inclusive Education, 19, 250-269. 
Sakız, H. (2016). Ability, examination and inclusive education: Stretching the hard lines of the educational system. Educational Process: International Journal, 5(1). 65-75.

Stark, O., \& Bloom, D. E. (1985). The new economics of labor migration. The American Economic Review, 75(2), 173-178.

Taneri, O. (2019). Kuramdan uygulamaya kapsayıcı eğitim. Ankara: Pegem Akademi Yayıncılık.

UNESCO. (2005). Guidelines for inclusion: ensuring access to education for all. UNESCO. 


\section{Ek 1}

\section{Temel Duygular}
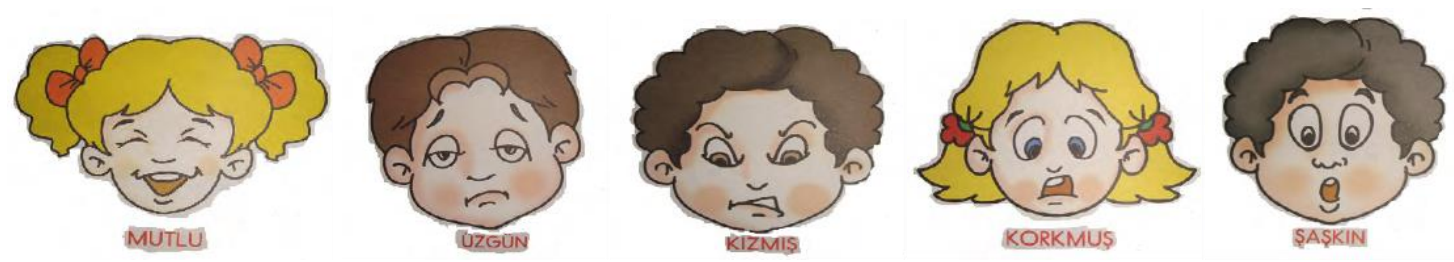

Ek 2

\section{Duygu İsimleri Listesi}

\begin{tabular}{lll} 
& \multicolumn{2}{l}{ Duygu listesi } \\
Acıma & Hayret & Pişmanlık \\
Acizlik & Hassasiyet & Neşe \\
Ait olmak & Öfke & Üzüntü \\
Alınma & Hüzün & İtikam \\
Anlaşıılmama & Sevgi & Bezginlik \\
Arınmışlık & Bıkkınlık & Cesaret \\
Așağılık Duygusu & Tasa & Keyif \\
Așk & Kin & Endişe \\
Ayıplama & Gerilim & Merak \\
Azim & Merhamet & Güven \\
Bağımsızlık & Gücenme & Efkar \\
Minnettarlık & Dinginlik & Ümit
\end{tabular}




\section{Ek 3}

Durum 1 Açıklama:

'Çevremizde herhangi bir yangın durumunda hemen itfaiyeyi aramalıyı. Çünkü İtfaiye çalışanlarının görevi, en yakın zamanda yangın yerine gelip yangını söndürmektir. İtfaiyeye 110 İTFAİYE numarasını arayarak ulaşabiliriz.' Öğretmen çocuklara Ek 4'teki itfaiye resmini gösterip itfaiyenin görevini ve telefon numarasını tekrarlatarak pekiştirme sağlar.

\section{Durum 2 Açıklama:}

'Çevremizde şiddet ve hırsızlık gibi bizi üzen olaylar olduğunda hemen polisi aramalıyız. Polisin görevi, bizim can ve mal güvenliğimizi sağlamak ve suçluları yakalamak için en yakın zamanda olay yerine gelmektir. Polise 155 POLİS İMDAT numarasını arayarak ulaşabiliriz.' Öğretmen çocuklara Ek 4'teki Polis İmdat resmini gösterip Polis İmdat'ın görevini ve telefon numarasını tekrarlatarak pekiştirme sağlar.

\section{Durum 3 Açıklama:}

'Çevremizde yaralanma veya hastalık gibi durumlarda hemen acil ambulansı aramalıyı. Acil ambulansın görevi, sağlık sorunu yaşadığımızda bizi en yakın hastaneye ulaştırmaktır. Acil ambulansa 112 ACİL numarasını arayarak ulaşabiliriz.' Öğretmen çocuklara Ek 4'teki acil yardım merkezi resmini gösterip görevini ve telefon numarasını tekrarlatarak pekiştirme sağlar.

Ek 4

İtfaiye Resmi

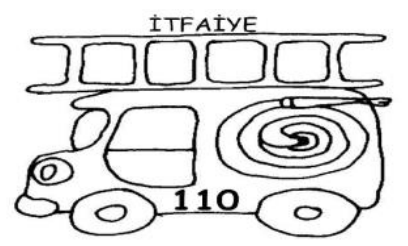

Polis Arabası Resmi

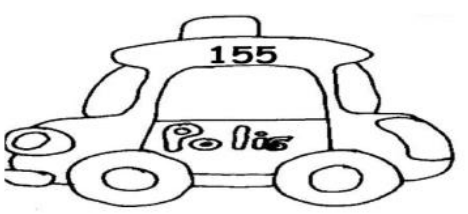

Ambulans Resmi

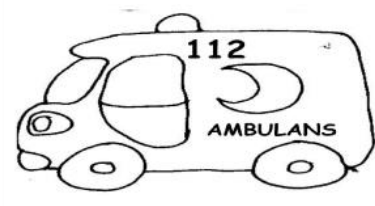




\section{Ek 5}

\section{Okul Öncesi Eğitimde Rehberlik Programı}

\section{İhtiyaç Analizi Formu (Anne-Baba ve Öğretmen)}

Sayın anne/baba/öğretmen,

Sizden doldurmanız istenen bu form, çocukların eğitsel, kişisel ve mesleki gelişimlerini desteklemek amacıyla uygulanan Okul Öncesi Eğitimde Rehberlik Programı'nda yer alan kazanımlardan çocuğun gelişim düzeyine ve ihtiyaçlarına uygun olanların belirlenmesi amacıyla kullanılacaktır. Liste halinde verilmiş olan kazanım ifadelerini okuyunuz ve çocuğunuz için ihtiyaç olarak gördügünüz ifadenin karşısına yeterlik düzeyini "Evet", "Kısmen", "Hayır" derecelemelerinden uygun gördüklerinizi işaretleyiniz.

\section{KAZANIMLAR}

1. Sinif kurallarina uyar.

2. Okula gidiş geliş yolundaki gördüklerini söyler.

3. Bağımsız iş yapmanın önemini fark eder.

4. Kendini tanıtan özellikleri bilir.

5. Temel duyguların (mutlu, üzgün, kızgın, korku, şaşkınlık) dışındaki duyguların neler olduğunu söyler.

6. Kendinde gördüğü olumlu özellikleri fark eder/söyler.
YETERLIKK

DÜZEYI

Evet Kismen Hayır


Ek 6

Sayın Öğretmen,

\section{Okul Öncesi Eğitimde Rehberlik Programı Gözlem Formu Örneği}

Bu form, sınıfınızda bulunan çocukların etkinlik sonrasında ulaştıkları yeterlik düzeylerini gözlemlemek amacıyla hazırlanmıştır. Sizlerden beklenen, etkinlik sonrasında çocukları gözlemlemek ve çocukta yeterince gelişmeyen veya desteklenmesi gereken davranışları tespit etmektir. Çocukları değerlendirirken, ifadelerde yer alan davranışları sergileme derecesine göre 'her zaman', 'kısmen' ve 'hiçbir zaman' seçeneklerinden uygun olanı işaretlemeniz beklenmektedir.

\section{GÖZLEM SORULARI}

Her Zaman

Kısmen

Hiçbir Zaman

Mesleklerin toplumda ne işe yaradığını söyler.

Mesleklerin toplumda ne işe yaradığının farkındadır.

Diş doktorlarının ne iş yaptığını söyler.

Hasta bakıcılarının ne iş yaptığını söyler. 